\title{
Evaluation on Soil Hardness in Riparian Forest Restoration along Kayan Ulu River, Sarawak, Malaysia
}

\author{
AINA NADIA NAJWA MOHAMD JAFFAR*, MOHD EFFENDI WASLI \& MUGUNTHAN \\ PERUMAL
}

\author{
Faculty of Resource Science and Technology, Universiti Malaysia Sarawak, 94300 Kota Samarahan, Sarawak, \\ Malaysia \\ *Corresponding author: ainanadianajwamj94@gmail.com
}

\begin{abstract}
Soil hardness plays a vital role in evaluating the physical properties of soil structure. With regards to the impact of compaction on practical forest management issues, most report and review forms were available. Thus, the aim of this study was to evaluate the soil condition in riparian forest restoration planted with indigenous species along Kayan Ulu River with special reference to soil hardness. Soil hardness was measured by using Hasegawa-type cone penetrometer from the surface soils to $100 \mathrm{~cm}$ depth, with a total of 48 random points for both study sites surveyed; restoration sites planted with Shorea macrophylla in year 1996 and 1998 (SPD96 and SPD98, respectively) for both on and between planting lines. Our findings indicated that, soil hardness in SPD98 was harder as compared to SPD96 at shallow depth presented in one drop penetrability. Likewise, soil penetration resistance on planting line in SPD98 was significantly higher than SPD96 at surface soils (0-20 cm) and subsurface soils $(20-40 \mathrm{~cm})$. A high number of strikes and soil penetration resistance indicate that the soils were highly compacted. However, there was no significant difference in term of soil penetration resistance between planting line. In order to avoid effects on tree productivity, it is recommended that in future, the evaluation of soil hardness should be determined during the early establishment for future restoration of riparian ecosystem.
\end{abstract}

Keywords: Riparian forest restoration, riparian ecosystem, Sarawak, soil hardness

Copyright: This is an open access article distributed under the terms of the CC-BY-NC-SA (Creative Commons Attribution Non CommercialShare Alike 4.0 International License) which permits unrestricted use, distribution and reproduction in any medium, for non-commercial purpose, provide the original work of the author(s) is properly cited.

\section{INTRODUCTION}

Riparian forest provides the ecological sustainability between terrestrial and river ecosystems in regulating the interaction, stabilizing the riverbanks from erosion, maintaining the biodiversity, storing the water and sediment (National Research Council, 2002; Schultz, Isenhart, Simpkins \& Colletti, 2004). The biogeochemical, ecological and hydrological vital functions of these forests bordering waterways are widely recognized in current management strategies, particularly in the tropics. Soil hardness mostly linked to a reduction in permeability to water and air. According to Batey (2009); Usaborisut and Ampanmanee (2015), the indicator of soil hardness comprises of bulk density, porosity and moisture content. It brings negative impact to limit root growth and plant development in forest management (Batey, 2009; Hamza \& Anderson, 2005). Soil penetration resistance expressed the average of soil hardness by its mechanical resistance on roots and has been found to be well correlated with root growth to sustain sufficient turgor pressure in the study sites (Hattori et al., 2013). In addition, soil hardness of the artificial planting with representative points had been expressed by one drop penetrability (ODP) (Ishizuka et al., 1998; Sakurai et al., 1995).

Most of the heavy equipment, due to their weight and size, have the tendency to compact the soils at deeper part even after 40 years logged-over (Hattori et al., 2013; Sivarajan, Maharlooei, Bajwa \& Nowatzki, 2018; Usaborisut \& Sukcharoenvipharat, 2011). However, compact soils also caused by natural conditions without any biotic such as human and animal disturbance involvement (Batey, 2009). The environmental impacts were an inevitable of the prolonged such as floods and heavy rains which occurred during the North East Monsoon Season between November to February in the riparian forest of Malaysia (Ng, Singh \& Thiruchelvam, 2018). According to An, Cheng, Sun, Wang and Li (2002); Balian and Naiman (2005); Tiegs, Leary, Pohl and Munill (2005), the distribution of riparian forest trees along the riverbanks area has been considered important in the river management and forest restoration.

With regard to the impact of compaction on practical forest management issues, most report and review forms such as those of Batey (2009); Hattori et al. (2013); Ishizuka et al. (1998) were available. Our previous studies have been conducted in restoration sites to examine different aspects of the soil properties existing in the riparian ecosystem (Jaffar, Wasli, Perumal, Lat \& Sani, 2018a, b; Perumal, Wasli, Ho, Lat \& Sani, 2015; 2017; Wasli et 
al., 2014). This study was conducted to determine the potential of indigenous species in relation to the soil hardness for future forest restoration strategies along the riparian ecosystem. Even within a specific field, the soil hardness may vary widely due to the spatial and temporal. Thus, the objective of this study was to evaluate the soil condition in riparian forest restoration planted with indigenous species along Kayan Ulu River with special reference to soil hardness.

\section{MATERIALS AND METHODS}

This study was conducted at Sampadi Forest Reserve (N01 34'13', E109 53'12'”) which is located along Kayan Ulu River, Lundu, Sarawak. The area receives more than 4,000 $\mathrm{mm}$ of rainfall annually with annual temperatures ranging from $23^{\circ} \mathrm{C}$ to $33^{\circ} \mathrm{C}$ (Department of Irrigation \& Drainage, 2016; Meteorological Department, 2016). Our previous studies reported that periodic inundation occurred with low fertility and nutrient status along the riparian forest of Kayan Ulu River, Lundu, Sarawak (Jaffar et al., 2018a, 2018b; Perumal et al., 2015, 2017). The soil type in the study area constituted of combination of sandstone, coarse-grained, humult Ultisols and sandy residual parent material (Perumal et al., 2015, 2017). The reforestation sites were previously logged-over in the past 40 years and most of the forests have lost their original structure of soils (Jaffar et al., 2018b). Based on in-situ observation, the common pioneer trees species found during site surveys were such genera as Aleurites (Euphorbiaceae), Amomum (Zingiberaceae), Cratoxylum (Clusiaceae), Dillenia (Dilleniaceae), Elaeocarpus (Elaeocarpaceae), Ficus (Moraceae), Hopea (Dipterocarpaceae), Ilex (Aquifoliaceae), Lithocarpus (Fagaceae), Norrisia (Loganiaceae), Pentace (Tiliaceae), Pentaspadon (Anacardiaceae), Sarcotheca (Oxalidaceae) and Vitex (Verbenaceae) (Jaffar et al., 2018b).

Six experimental plots sized $25 \mathrm{~m}$ x $25 \mathrm{~m}$ were constructed for stands of two ages at the restoration sites. $S$. macrophylla trees were planted in the year 1996 and 1998. The abbreviation of restoration sites were coded as SPD96 for planted trees in the year 1996 and SPD98 for the planted trees in the year 1998. The treatment on improving the light penetration had been done by bush cutting and canopy opening on planting line (OPL) once a year meanwhile there is no clearance on undergrowth pioneer vegetation located between planting line (BPL). Our previous studies reported that the growth performance of planted $S$. macrophylla in terms of mean annual increment in height and diameter (MAIH and MAID) in SPD96 were significantly higher than SPD98 (Jaffar et al., 2018b; Perumal et al., 2017).

In this study, soil hardness was measured by using Hasegawa-type cone penetrometer (Daito Techno Green Co., Tokyo, H-60) from the surface soils to $100 \mathrm{~cm}$ depth, with a total of 48 random points for all the study sites surveyed; SPD96 and SPD98. The evaluation of soil hardness was expressed in ODP as shown in Figure 1. The horizontal axis shows the penetrating depth $(\mathrm{cm})$ per one drop of weighing meanwhile vertical axis represents the cumulative depth $(\mathrm{cm})$. The smaller the value of ODP $(\mathrm{cm})$ represents the harder the soils. Soil hardness was classified using the value plotted on the horizontal axis as follows; very hard, ODP less than 0.5; hard, ODP between 0.5 to 1.0; moderate, ODP between 1.0 and 2.0; soft, ODP more than 2.0 (Ishizuka et al., 1998; Sakurai et al., 1995).

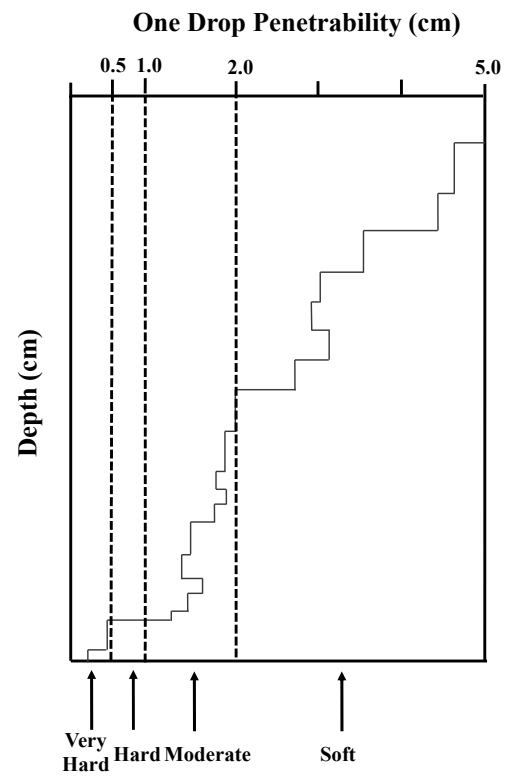

Figure 1. One drop penetrability (ODP) and definition of soil hardness (Ishizuka et al., 1998; Sakurai et al., 1995). 
The soil penetration resistance was calculated by the following formula:

$$
\mathrm{E}=\mathrm{M} \times \mathrm{G} \times \mathrm{H} \times \mathrm{C}
$$

where $\mathrm{E}$ is the soil penetration resistance $(\mathrm{J}), \mathrm{M}$ is the mass of the penetrometer $(2.0 \mathrm{~kg}), \mathrm{G}$ is the gravitational acceleration $\left(9.8 \mathrm{~ms}^{-2}\right), \mathrm{H}$ is the vertical drop of the penetrometer weight $(0.5 \mathrm{~m})$ and $\mathrm{C}$ is the count of strikes for each depth (Hattori et al., 2013, Jaffar et al., 2018b). The data on soil penetration resistance was statistically analysed by using Student's t-test to compare significant difference between the planting years. The statistical test was performed using SPSS version 17.0 for windows.

\section{RESULTS AND DISCUSSION \\ Soil Hardness of SPD96 and SPD98 Restoration Sites along Riverbanks of Kayan Ulu River, Lundu, Sarawak}

The evaluation of soil hardness is an important component of land degradation in forest management as it reflects the productivity of the forest areas (Dinis, Surovy, Ribeiro \& Oliveira, 2014; Merotto \& Mundstock, 1999). Based on the results, the ODP value at the area in SPD96 on planting line was less than 4.0 at the surface $13.7 \mathrm{~cm}$ to $100.0 \mathrm{~cm}$ depth (Figure 2). This indicates that the soil was hard to very hard as compared to the surface ranging from 0 to $13.6 \mathrm{~cm}$ at depth. The ODP value at the area in SPD96 between planting line was more than 4.0 at the surface of $0 \mathrm{~cm}$ to $22.3 \mathrm{~cm}$ and followed by $26.0 \mathrm{~cm}$ to $30.7 \mathrm{~cm}$ at depth. This indicates that soil was less compacted for planted $S$. macrophylla to penetrate into soils. The distribution pattern of soil hardness was uniform within the whole experiment sites in SPD98 for both on planting and between planting lines. ODP value on planting line plot below $80.0 \mathrm{~cm}$ depth corresponded to very hard in soil hardness for most of the points. For example, the pattern of soil hardness shows that the ODP value ranged from 0.7 to $0.3 \mathrm{~cm}$. The soil was very hard in most of the readings leading to a large number of counts. Based on the pattern of soil hardness on planting line, the counts for penetrating from soils surface to $100.0 \mathrm{~cm}$ depth were depicted schematically from $0.1 \mathrm{~cm}$ to $2.7 \mathrm{~cm}$. Soil hardness in SPD98 between planting line was similar at every examined point. The ODP value was more than $2.3 \mathrm{~cm}$ from surface soils to $12.4 \mathrm{~cm}$ depth which might be due to the well-developed root mat layers. Below the depth, it ranged from $0.3 \mathrm{~cm}$ to $2.0 \mathrm{~cm}$ of ODP and thus showing that the root penetration was with very strong resistance. ODP value at below $79.3 \mathrm{~cm}$ depth was corresponded to very hard soil hardness in most of the points. For example, the pattern of soil hardness shows the ODP value below $0.5 \mathrm{~cm}$. Thus, this indicated that severe distribution of root elongation to a depth of $100 \mathrm{~cm}$ for both on and between planting line had been occurred.

The results indicated that soil penetration resistance in SPD96 was significantly lower than SPD98 at surface soil (0-20 cm depth) on planting line (Figure 3). Although there was significant difference found at both surface soils (0-20 cm depth) and subsurface soils (20-40 cm depth) of the OPL, but it was observed that there was no significant difference on soil penetration resistance of the BPL. In SPD96 (20 years-old), the soil penetration resistance on planting line at surface soils $0-20 \mathrm{~cm}$ depth shows $6.8 \mathrm{~J} \mathrm{~cm}^{-1}$ followed by $12.6 \mathrm{~J} \mathrm{~cm}^{-1}$ in $20-40 \mathrm{~cm}$ depth at subsurface soils. However, the soil penetration resistance was high at subsurface soils depth of $40-100 \mathrm{~cm}$ ranging from $20.0 \mathrm{~J} \mathrm{~cm}^{-1}$ to $45.9 \mathrm{~J} \mathrm{~cm}^{-1}$. Soil penetration resistance on planting line in SPD98 (18 years-old) for surface soils at the depth of 0-20 cm was $9.0 \mathrm{~J} \mathrm{~cm}-1$ followed by $16.3 \mathrm{~J} \mathrm{~cm}^{-1}$ at subsurface soils $20-40 \mathrm{~cm}$ depth. Meanwhile, soil penetration resistance in SPD98 for subsurface soils $(30-100 \mathrm{~cm})$ was varied which ranged from $19.0 \mathrm{~J} \mathrm{~cm}^{-1}$ to $36.7 \mathrm{~J} \mathrm{~cm}^{-1}$ thus indicating water content to be higher in the surface layer then gradually decreased toward the subsurface layer.

The soil penetration resistance between planting line for surface soils at depth $0-20 \mathrm{~cm}$ shows $6.4 \mathrm{~J} \mathrm{~cm}{ }^{-1}$, followed by $12.8 \mathrm{~J} \mathrm{~cm}^{-1}$ at depth soils $20-40 \mathrm{~cm}$. At subsurface soils $(40-100 \mathrm{~cm})$, the results were higher than surface soils ranged from $21.4 \mathrm{~J} \mathrm{~cm}^{-1}$ to $40.0 \mathrm{~J} \mathrm{~cm}^{-1}$, reflecting soil water storage was lower, due to the barrier of these waterlogged conditions formed on the surface. This was supported by Greacean and Sands (1980) stating that high soil penetration resistance typically has lower water infiltration rates. Meanwhile, soil penetration resistance between planting line in SPD98 for surface soils at the depth of 0-20 cm was $8.8 \mathrm{~J} \mathrm{~cm}^{-1}$ followed by $15.8 \mathrm{~J} \mathrm{~cm}^{-1}$ at subsurface soils 20-40 cm depth. Meanwhile, soil penetration resistance in SPD98 for subsurface soils (40-100 $\mathrm{cm}$ ) was between $19.0 \mathrm{~J} \mathrm{~cm}^{-1}$ to $32.9 \mathrm{~J} \mathrm{~cm}^{-1}$ indicating compaction was highly due to the limited water absorption that inhibits the lateral roots. Hattori et al. (2013) mentioned that during the early planting period, inhibition of lateral root elongation in high soil penetration resistance increased the mortality rates of Dipterocarp trees. The bulk density (BD) value (data not shown) decreases with increasing soil penetration resistance. Thus, this trend was similar with our previous studies whereby it had lower BD with $1.36 \mathrm{~g} \mathrm{~mL}^{-1}$ at subsurface soils in SPD98 and higher content of soil organic matter as compared to the subsurface soils in SPD96 with $1.32 \mathrm{~g} \mathrm{~mL}^{-1}$ bulk density of soils (Perumal et al., 2015). High soil penetration resistance with high water content enhanced decomposition activities by soil microbes. Soil penetration resistance in SPD98 shows higher value than SPD96 which indicate that soils in SPD98 has greater resistance against the root penetration. In general, soil penetration resistance with value more than $15.0 \mathrm{~J} \mathrm{~cm}^{-1}$ lead to critical root growths which were determined experimentally by Canarache 
(1990). Despite that, soil penetration resistance values between 2.6 to $10.0 \mathrm{~J} \mathrm{~cm}^{-1}$ cause some limitations for root growth. This was supported by Hattori et al. (2013), stating that the value of soil penetration resistance with more than $5.2 \mathrm{~J} \mathrm{~cm}^{-1}$ at the depth of $0-60 \mathrm{~cm}$ could cause the limitation of root growth in the compacted area. Soil penetration resistance values with less than $5.2 \mathrm{~J} \mathrm{~cm}^{-1}$ indicate that the soils were in undisturbed area.

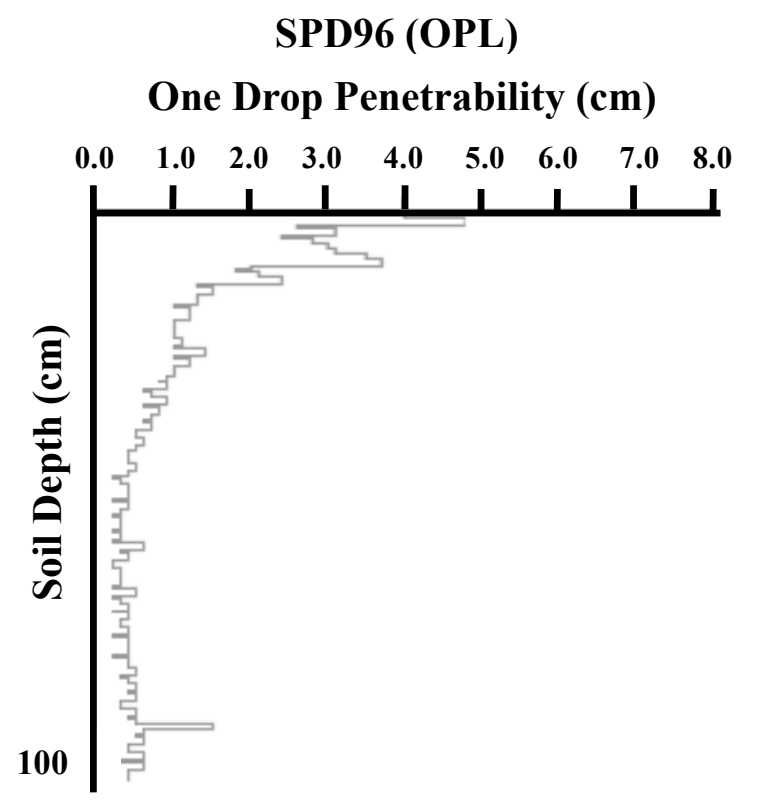

SPD98 (OPL)

One Drop Penetrability (cm)

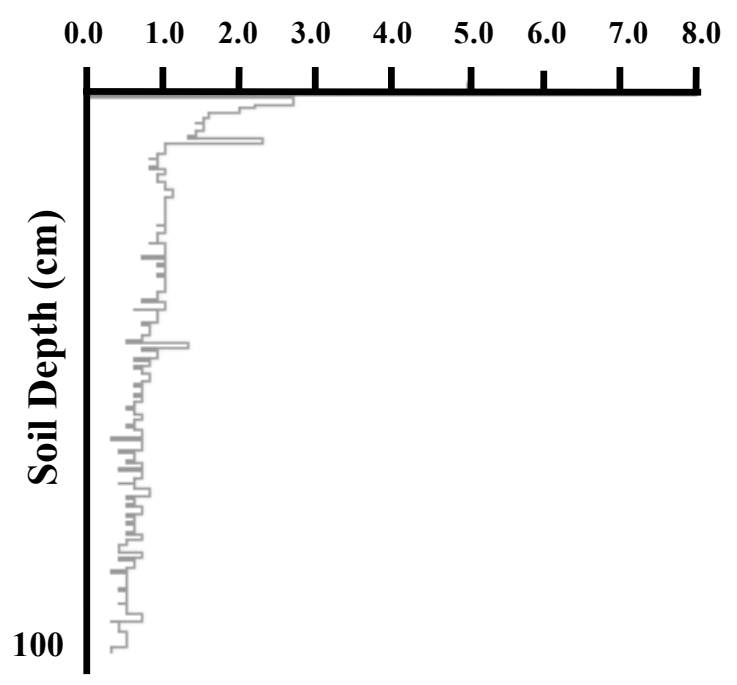

SPD96 (BPL) One Drop Penetrability (cm)

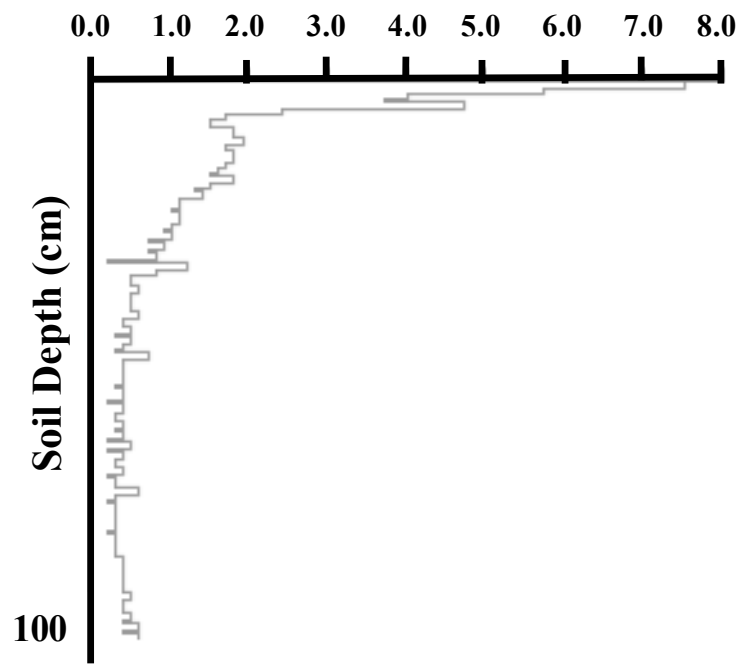

SPD98 (BPL) One Drop Penetrability $(\mathrm{cm})$

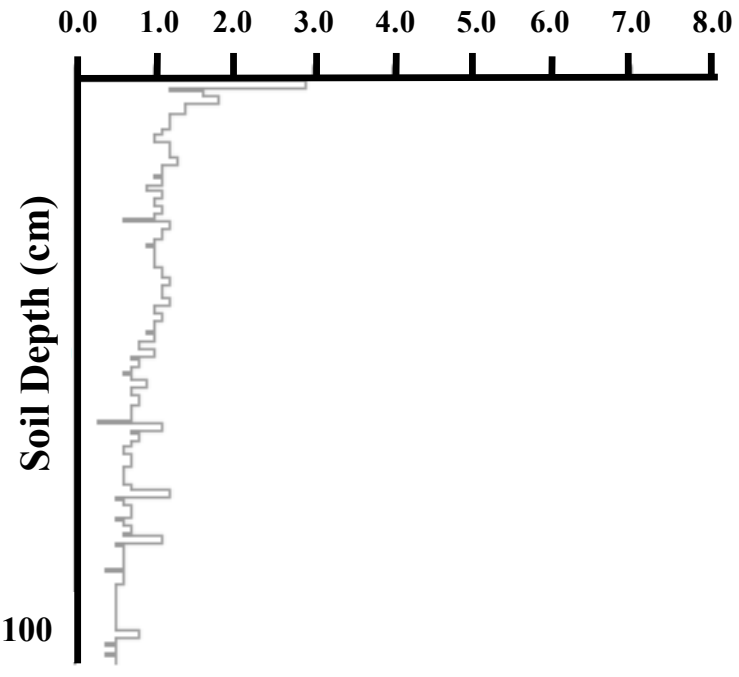

Figure 2. Pattern of soil hardness in Sampadi Forest Reserve restoration in plot aged 20 years (SPD96) and 18 years (SPD98) for both on planting line and between planting line; OPL refers to on planting line; BPL refers to between planting line.

Very hard soil conditions were found in some parts of the study sites as shown in a pattern of soil hardness. This was ascribed to anthropogenic activities including hardness from degraded land and selective logging by the bulldozer based on the history of the forest (NREB, 2010; Wright, 2005). Soils which were highly compacted at the deeper part was also caused by the wet soils that reflect the impact of periodic inundation especially during the monsoon season in Sarawak as mentioned in our previous study by Perumal et al. (2017). A comprehensive study by Hattori et al. (2013) was carried out between soil penetration resistance in the compacted area and undisturbed area. The findings show that the value of $6.8 \mathrm{~J} \mathrm{~cm}^{-1}$ and $14.5 \mathrm{~J} \mathrm{~cm}^{-1}$ at surface soils and subsurface soils, respectively in the compacted area. Meanwhile, the value of soil penetration resistance in an undisturbed area had two to three times less than the compacted area (Hattori et al., 2013). Thus, the values obtained in our study site was mostly categorized as compacted in both surface and subsurface layers. Generally, soil hardness of planted S. macrophylla 
in SPD96 was lower as compared to SPD98. Nonetheless, these results to higher survival and favourable growth performance of planted S. macrophylla in SPD96 as compared to SPD98 in our previous studies (Jaffar et al., 2018b; Perumal et al., 2017). Although the stand productivity is altered by the changes of soil compaction, the above-ground growth could adapt, if the plant can obtain sufficient water and nutrient (Jaffar et al., 2018b; Whitmore \& Whalley, 2009).
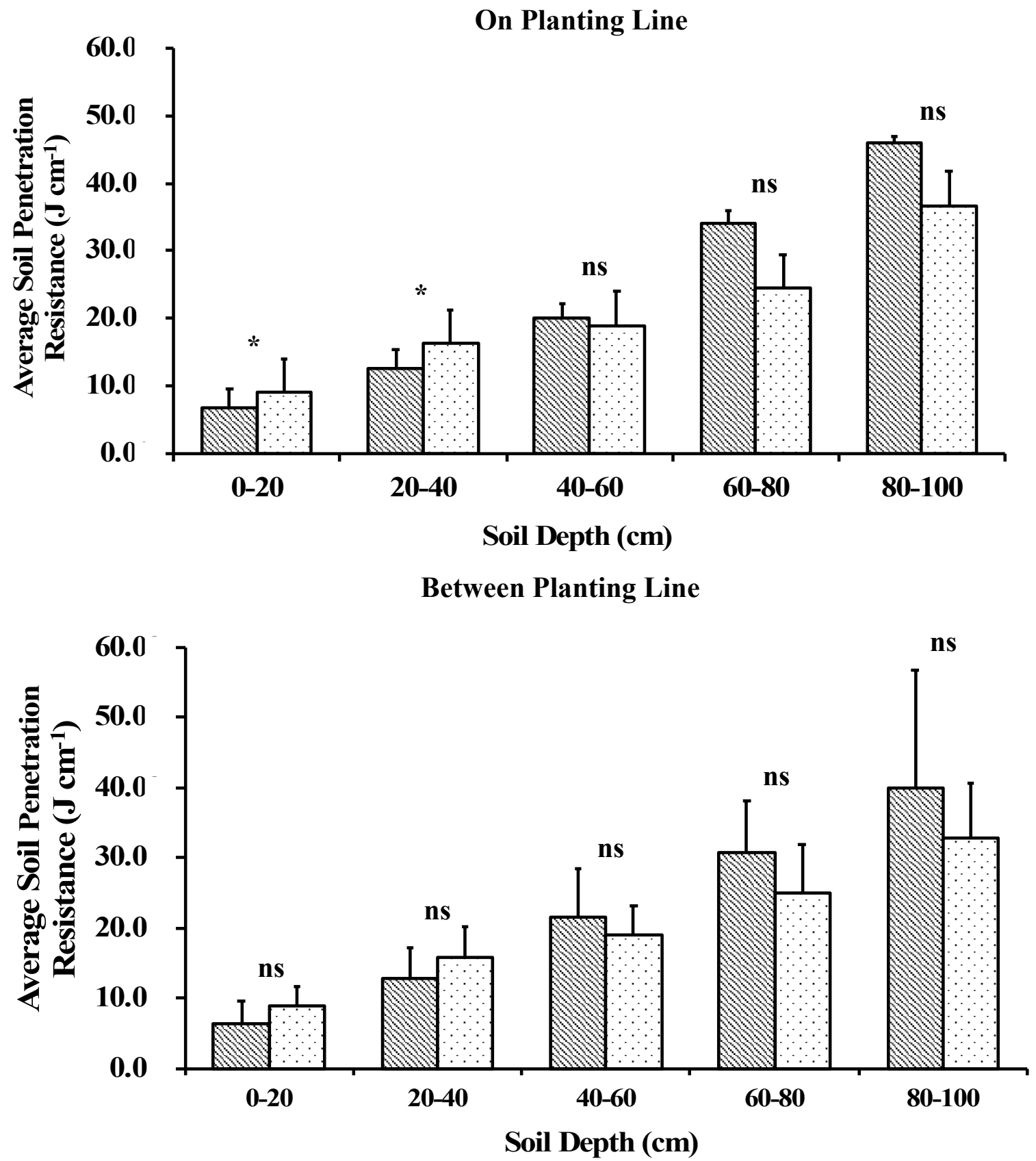

Legends

Soil Penetration Resistance in SPD96 $\left(\mathrm{J} \mathrm{cm}^{-1}\right)$

Soil Penetration Resistance in SPD98 $\left(\mathrm{J} \mathrm{cm}^{-1}\right)$

Figure 3. Average soil penetration resistance at depth $100 \mathrm{~cm}$ for both on planting and between planting lines in SPD96 and SPD98; * in the same depths means significant differences at 5\% using Student's t-test; ns means no significant differences at 5\% using Student's t-test. 


\section{CONCLUSIONS}

In conclusion, soil hardness of planted S. macrophylla in SPD98 was harder as compared to SPD96 at shallow depth. This suggests that high soil penetration resistance indicate that the soils were compacted nearby the riparian forest of Kayan Ulu, Sarawak, Malaysia. However, planted S. macrophylla at restoration sites were able to thrive under extreme conditions such as heavy rain and annual flooding which naturally occurs around the rivers. The survivability and growth performances of planted S. macrophylla from our previous studies grow vigorously with respect to other environmental conditions such as microclimate and species composition. Therefore, it is recommended that the evaluation of soil hardness should be determined during the early establishment for future restoration of riparian ecosystem.

\section{ACKNOWLEDGEMENTS}

This research was financially supported by following grant entities: Research Acculturation Grant Scheme (RAGS) (RAGS/g(2)/914/2012(15)) from Ministry of Higher Education, Malaysia; Grant-in-Aid for scientific research purpose by the Japan-Malaysia Association (JMA) and NPO Rainforest Sarawak. Authors wish to express gratitude to the Director and staff of the Forest Department, Sarawak for their supportive assistance during the duration of this study. Authors would also like to extend thanks to local villagers from the study area for their kind co-operation and assistance during the field survey.

\section{REFERENCES}

An, S., Cheng, X., Sun, S., Wang, Y., \& Li, J. (2002). Composition change and vegetation degradation of riparian forests in the Altai plain, NW China. Plant Ecology, 164, 75-84.

Balian, E. V., \& Naiman, R. J. (2005). Abundance and production of riparian trees in the lowland floodplain of the Queets River, Washington. Ecosystems, 8, 841-861.

Batey, T. (2009). Soil compaction and soil management. Soil Use and Management, 25, 335-345.

Canarache, A. (1990). Penetr- a generalized semi-empirical model estimating soil resistance to penetration. Soil and Tillage Research, 16, 51-70.

Department of Irrigation and Drainage. (2016). Hydrological Year Book Department on Irrigation and Drainage 1995-2016. Malaysia: Irrigation and Drainage Department, Kuching, Sarawak.

Dinis, C., Surovy, P., Ribeiro, N., \& Oliveira, M. R. G. (2014). The effect of soil compaction at different depths on cork oak seedling growth. New Forests, 46(2), 235-246.

Greacen, E. L., \& Sands, R. (1980). A review: Compaction of forest soils. Australian Journal of Soil Resources, 18, 163-189.

Hamza, M. A., \& Anderson, W. K. (2005). Soil compaction in cropping systems: a review of the nature, causes and possible solutions. Soil Tillage Research, 82(2), 121-145.

Hattori, D., Kenzo, T., Irino, K. O., Kendawang, J. J., Ninomiya, I., \& Sakurai, K. (2013). Effects of soil compaction on the growth and mortality of planted Dipterocarp seedling in a logged-over tropical rainforest in Sarawak, Malaysia. Forest Ecology and Management, 310, 770-776.

Ishizuka, S., Tanaka, S., Sakurai, K., Hirai, H., Hirotani, H., Ogino, K., Lee, H. S., \& Kendawang, J. J. (1998). Characterization and distribution of soils at Lambir Hills National Park in Sarawak, Malaysia, with special reference to soil hardness and soil texture. Tropics, 8, 31-44.

Jaffar, A. N. N., Wasli, M. E., Perumal, M., Lat, J., \& Sani, H. (2018a). Assessment of soil hardness expressed by one drop penetrability at forest restoration sites along Kayan Ulu River, Sarawak, Malaysia. In N. Ibrahim, N., M.H. Che Othman, S.R. Feroz, F. Sairi \& M.A. Senam (Eds.), The 15th Symposium of Malaysia Society of Applied Biology (pp. 28-35). Selangor, Malaysia: Malaysia Society of Applied Biology, Universiti Kebangsaan Malaysia.

Jaffar, A. N. N., Wasli, M. E., Perumal, M. Lat, J., \& Sani, H. (2018b). Effect of soil compaction and relative light intensity on survival and growth performance of planted Shorea macrophylla (de Vriese) in riparian forest along Kayan Ulu River, Sarawak, Malaysia. International Journal of Forestry Research, 2018, 1-11.

Merotto, A., \& Mundstock, C. M. (1999). Wheat root growth as affected by soil strength. Revista Brasileira de Ciencias do Solo, 23, 197-202.

Meteorological Department. (2016). Weather Data (Air Temperature) 2010-2016. Malaysia: Meteorological Department, Kuching, Sarawak, Malaysia.

National Research Council. (2002). Riparian areas: functions and strategies for management. Washington, US: National Academy Press.

Natural Resource and Environment Board (NREB). (2010). Environmental impact assessment for the proposed forest plantation under LPF/0042 at the Sampadi Area LPF/0042. Malaysia: Sampadi Area, Kuching Division, Sarawak.

Ng, Y. Y., Singh, M. S. J., \& Thiruchelvam, V. (2018). Performance analysis of 60-min to 1-min integration time rain rate conversion models in Malaysia. Journal of Atmospheric and Solar Terrestrial Physics, 167, 13-22. 
Perumal, M., Wasli, M. E., Ho, S. Y., Lat, J., \& Sani, H. (2015). Soil morphological and physicochemical properties at reforestation sites after enrichment planting of Shorea macrophylla in Sampadi Forest Reserve, Sarawak, Malaysia. Borneo Journal of Resource Science and Technology, 5(2), 28-43.

Perumal, M., Wasli, M. E., Ho, S. Y., Lat, J., \& Sani, H. (2017). Survivorship and growth performance of Shorea macrophylla (de Vriese) after enrichment planting for reforestation purpose at Sarawak, Malaysia. OnLine Journal of Biological Sciences, 17(1), 7-17.

Sakurai, K., Puriyakorn, B., Preechapanya, P., Tanpibal, V., Muangnil, K., \& Prachaiyo, B. (1995). Improvement of biological productivity in degraded lands in Thailand III: Soil hardness measurement in the field. Tropics, 4, 151-172.

Schultz, R. C., Isenhart, T. M., Simpkins, W. W., \& Colletti, J. P. (2004) Riparian forest buffers in agroecosystemslessons learned from the Bear Creek Watershed, central Iowa, USA. Agroforestry System, 61, 35-50.

Sivarajan, S., Maharlooei, M., Bajwa, S. G., \& Nowatzki, J. (2018). Impact of soil compaction due to wheel traffic on corn and soybean growth, development and yield. Soil and Tillage Research, 175, 234-243.

Tiegs, S. D., Leary, J. F. O., Pohl, M. M., \& Munill, C. L. (2005). Flood disturbance and riparian species diversity on the Colorado River Delta. Biodiversity and Conservation, 14, 1175-1194.

Usaborisut, P., \& Ampanmanee J. (2015). Compaction properties of silty soils in relation to soil texture, moisture content and organic matter. American Journal of Agricultural and Biological Science, 10, 178-185.

Usaborisut, P., \& Sukcharoenvipharat, W. (2011). Soil compaction in sugarcane fields induced by mechanization. American Journal of Agricultural and Biological Science, 6(3), 418-422.

Wasli, M.E., Sani, H., Ho, S. Y., Perumal, M., Zainudin, Z. A, Lat, J., \& Lee, P.S. (2014). Preliminary assessment on the growth performance of Dryobalanops beccarii dyer planted under enrichment planting technique at Gunung Apeng Forest Reserve, Sarawak, Malaysia. Kuroshio Science, 8, 45-52.

Whitmore, A. P., \& Whalley, W. R. (2009). Physical effects of soil drying on roots and crop growth. Journal of Experimental Botany, 60(10), 2845-2857.

Wright, S. J. (2005). Tropical forests in a changing environment. Trends in Ecology and Evolution, 20(10), 553560. 